SOUNDPROOF ROOM 



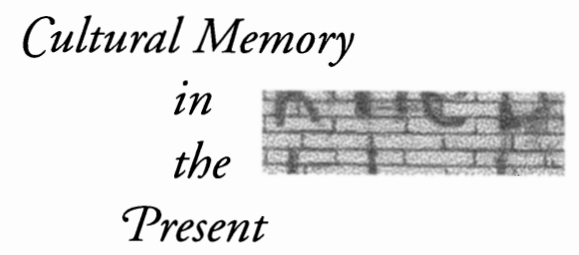

Mieke Bal and Hent de Vries, Editors 



\title{
SOUNDPROOF ROOM
}

\author{
Malraux's Anti-Aesthetics
}

Jean-François Lyotard

Translated by Robert Harvey

STANFORD UNIVERSITY PRESS

STANFORD, CALIFORNIA

2001 
Stanford University Press

Stanford, California

(C) 200 by the Board of Trustees of the

Leland Stanford Junior University

Assistance for the translation was provided by the French Ministry of Culture.

Soundproof Room: Malraux's Anti-Aesthetics

was originally published in French in 1998 under the title

Chambre sourde: L'Antiesthétique de Malraux,

(C) 1993, Éditions Galilée.

Printed in the United States of America

on acid-free, archival-quality paper.

Library of Congress Cataloging-in-Publication Data

Lyotard, Jean François.

[Chambre sourde. English]

Soundproof room : Malraux's anti-aesthetics / Jean François Lyotard; translated by Robert Harvey.

p. $\mathrm{cm} .-$ (Cultural memory in the present)

Includes bibliographical references.

ISBN 0-8047-3749-5 (cloth : alk. paper) — ISBN 0-8047-3750-9

(pbk. : alk. paper)

I. Malraux, André, 190I-1976-Criticism and interpretation.

I. Title. II. Series.

PQ2625.A716 z6965813 200I

$843^{\prime} .912-\mathrm{dc2}$ I

Original Printing 200I

Last figure below indicates year of this printing:

$\begin{array}{llllllllll}\text { I0 } & 09 & 08 & 07 & 06 & 05 & 04 & 03 & 02 & \text { OI }\end{array}$

Typeset by James P. Brommer in II/13.5 Garamond 
With thanks to Emory University,

Steven E. Sanderson,

and Dalia Judovitz 
